enteral administration of hypertonic saline. Apparently the surgeon wished to use physiological saline (so-called $0.9 \% \mathrm{w} / \mathrm{v}$ ) but prescribed "normal saline"; so the pharmacist made up normal saline $(58.5 \mathrm{~g} / \mathrm{l})$, which is six times as strong, and this was given to the patient.

This regrettable accident reinforces the need to abandon the use of "normal" (and of $\%$ ) in medicine and in chemistry to describe the concentration of a solution; this must be specified in appropriate SI units except for substances such as insulin where arbitrary units are still necessary. So physiological saline is $150 \mathrm{mmol} / 1$ (strictly 154) or $9 \mathrm{~g} / \mathrm{l}$, and chemically normal saline is $1 \mathrm{~mol} / 1$. "Isotonic saline" is an acceptable alternative name for the former. Regrettably in Britain both Boots (Polyfusor) and the British Pharmaceutical Codex maintain the dangerous "normal" name.

Department of Chemical Pathology,

D N BARON

Royal Free Hospital,

Lonuon NW3

\section{Salt overdosage}

SIR,-Salt overdosage in adults is extremely rare, and conclusions about treatment will inevitably be open to debate. The fact that only two of the patients reported in the literature have survived would suggest that conventional treatment, which recommends a slow reduction in serum osmolality, is ineffective. Of those referred to by $\operatorname{Dr} R A$ Goodbody and others (29 November, p 517) Capper's case is in fact a report of my patient, and Schatz's case is difficult to assess as accurate estimations of serum osmolality were not available in 1937 .

It is difficult within the confines of a short report to do more than state the facts of the case. However, I attempted to emphasise that the treatment of my patient involved a rapid reduction in serum osmolality and to explain why, in the light of published animal experimentation, this might theoretically be successful provided treatment was started early enough. Dr Carol Fitzpatrick (29 November, $p$ 517) suggests that convulsions in my patient were due to cerebral oedema. In fact I wrote (15 November, p 386), "there is an ... increase in CSF volume, and this, with brain cell overhydration, explains the abnormal lumbar puncture results in our patient." I had thought that brain cell overhydration and cerebral oedema were synonymous. The important point is that treatment was started too late. The fact that cerebral oedema developed implies that the brain cells were already hyperosmolar, owing either to an increase in intracellular sodium or to the formation of idiogenic osmoles as described by McDowell. ${ }^{1}$ Treatment, to be successful, should be started before the situation arises.

Royal West Sussex Hospital

\section{R C M MCGOURAN} Richard's, Chichester

1 McDowell, $\underset{\text { American }}{\mathrm{M} \text { fournal }} \mathrm{E}$ of Physiology, 1955, 180,545.

Activated charcoal in treatment of poisoning

SIR,-We read with interest your recent leading article on childhood poisoning (29 November, $p$ 483) and are in agreement with the opinions it contains. We note, however, that you make no mention of the role of activated charcoal. Although this material has been recommended as part of the initial treatment of poisoned patients ${ }^{1-3}$ and there is both in-vitro ${ }^{4}$ and in-vivo evidence in animals, ${ }^{5}$ we have been unable to find any reports of its efficacy in the treatment of poisoned patients.

We are currently undertaking a study on the role of activated charcoal in the initial treatment of poisoned patients and we would therefore appreciate hearing from any of your readers who have had personal experience in this field, especially with objective findings.

Peter Crome ROY GOULDING GLYN N Volans

National Poisons Information Service, Cross Hospital,

Holt, L E, and Holz, P H, fournal of Pediatrics, $1963,63,306$

British Medical fournal, 1972, 3, 487 .

Corby, D G, and Decker, W J, Pediatrics, 1974 54, 324

Tecker, W J, Combs, H F, and Corby, D G, 13, 454

Lipscomb, D J, and Widdop, B, Archives of
Toxicology, 1975, 34, 37.

\section{Volunteers and the aftermath of stroke}

SIR,-I greatly admire the work of speech therapists and have worked happily and fruitfully with them now for $2 \frac{1}{2}$ years in the Volunteer Stroke Scheme. We hope to extend this splendid co-operation in the future Therefore I have no heart to enter into any argument about the few points Miss Margaret Edwards raises in her letter (22 November, $p$ 460)

Mildly, I would simply say a few words. Volunteers should be untrained specifically so that they work on the ordinary humanfellowship level and do not fall into the old trap of a little learning proving dangerous. In this way the work of professional and amateur can complement each other, with speech therapists advising the volunteer, as already happens within this scheme.

If there is any "magic" in untrained volunteers working with stroke patients, it is only the power of an actively caring community. Therefore please let no one fear we are usurping or competing with a professional function. These very hard-hit patients and their families need both expert professional treatment and amateur help in the home and community.

Great Missenden, Bucks

V EATON GRIFFITH

\section{C-Film as a contraceptive}

SIR,-Drs N Raabe and O Frankman (1 November, $p$ 286) imply that the reason for the high failure rate in the Family Planning Association's trial of C-Film was poor patient instructions.

We too are surprised at the difference between our trial results and those obtained by Drs Raabe and Frankman, but we want to point out that, besides receiving detailed verbal and written instructions on the use of C-Film, our patients were given a demonstration on how to insert the film.

Michael V SMITh W BOUNDS

Family Planning Association,

London $W 1$

Disposal of disposable colostomy appliances

SIR,-In 1971 we published the results of a survey we had conducted into the problems of patients with permanent colostomies following resection of the rectum for cancer (14 August 1971, p 413). We then noted that $48 \%$ of the patients reviewed were using disposable appliances and many of these patients complained of difficulties in disposing of the appliances after use. Recently we have conducted a further study, this time of patients here in the Cleveland area. We find that now some $92 \%$ of colostomy patients are using disposable one-piece plastic appliances and many of them are having increasing difficulties in getting rid of the used appliances. Refuse collectors are reluctant to take fouled appliances away and indeed many patients are too embarrassed to use dustbins for this purpose. The full plastic appliances are difficult to burn, so that patients are increasingly resorting to a policy of puncturing or cutting the appliance to make it sink and then flushing it down the toilet.

However, this is not the end of the story. These appliances are virtually indestructible and when flushed into the local sewers they pass through the system intact and end up in the North Sea. Anyone walking along the beaches of North Yorkshire and Cleveland can now count many indestructible plastic stoma appliances with their contents almost intact at the high tide mark. Surely this is not the ideal place for us to dump these sequelae of modern surgical technology?

These used appliances represent both an aesthetic and a health hazard on our seashores, but they also represent the failure of many local authorities to provide the adequate disposal facilities which many stoma patients require in order to enable them to dispose of their excreta in a humane and socially acceptable way.

H BRENDAN DEVLIN JOSEPHINE A PLANT

North Tees General Hospital,

Stockton-on-Tees,

Cleveland

\section{Venous thromboembolism and}

anticoagulants in pregnancy

SIR,-In your leading article on this subject (22 November, p 421) emphasis is naturally first given to pulmonary embolism. However, I was sorry to see that no mention was made of the apalling morbidity which affects women who suffer deep vein thrombosis during pregnancy or the puerperiumnamely, the subsequent development of the postphlebitic limb syndrome.

The diagnosis and treatment of deep vein thrombosis is of primary importance in the prevention of pulmonary embolism. The prevention of the development of a deep vein thrombosis is essential to spare the patient years of suffering from oedema, pain eczema, and ulceration and the likely development of a subsequent deep vein throm- 